\title{
Isolated Diffuse Mesangial Sclerosis Presenting as Steroid Resistant Nephrotic Syndrome After Infancy
}

\author{
Amisha Undani ${ }^{1}$, Mahaleengam Vijaya kumar $^{1}$, Nageswaran Prahlad ${ }^{1}$, Ekam baram Sudha ${ }^{1}$ \\ ${ }^{1}$ Department of Pediatric Nephrology, Mehta Children's Hospitals, Chennai, India.
}

\section{Abstract}

Diffuse mesangial sclerosis presents with corticosteroid resistant nephrotic syndrome and progressive renal failure usually in the first year of life. With limited resources for genetic mutation studies, kidney biopsy along with clinical findings helps to suspect possible underlying gene mutation. This child with female phenotype and genotype presented with nephrotic features for the first time after one year of age.

Keywords: Diffuse mesangial sclerosis, Gene mutation, Renal biopsy, Renal failure.

Corresponding Author: Dr. M. Vijayakumar, Consultant Pediatric Nephrologist, Mehta Children's Hospitals, No.2(e) Mc Nichols Road, 3rd Lane, Chetput, Chennai 600 031, Tamil nadu, India.

Received: July 2018

Accepted: August 2018

\section{Introduction}

Diffuse mesangial sclerosis (DMS) is a rare but well defined entity which usually presents in first year of life. ${ }^{[1]}$ Treatment is supportive as they are corticosteroid resistant. The cause of death is usually due to infections. We report a case of isolated DMS presenting as steroid resistant nephrotic syndrome (SRNS) in a genotypic female child who was asymptomatic in her infancy. This uncommon feature of first presentation of DMS after one year of life should be noted.

\section{Case Report}

A 13 months old female child born to non-consanguineous parents presented with generalized swelling of body gradually increasing since last 7 days with decreased urine output. She had no history of hematuria or history suggestive of etiology pointing to secondary causes of nephrotic syndrome (NS). Her antenatal and birth history were normal and there was no family history of renal disease. On examination, there was anasarca, no hypertension, normal genitalia and normal ocular examination. Her investigations showed nephrotic range proteinuria (spot urine protein to creatinine ratio of 7.4); urine albumin 4+, no sugar, 4-6 pus cells/hpf and no RBCs. Serum showed albumin of $2.0 \mathrm{~g} / \mathrm{dL}$; cholesterol $265 \mathrm{mg} / \mathrm{dL}$ and creatinine of $0.7 \mathrm{mg} / \mathrm{dL}$. Ultrasound (USG) abdomen showed bilateral marginal renomegaly and moderate ascites. After ruling out any active infection and tuberculosis by Mantoux testing and chest X-ray, daily steroids at $60 \mathrm{mg} / \mathrm{m}^{2}$ was started and after 4 weeks of daily steroids, her urine albumin was $4+$ with serum albumin of $1.8 \mathrm{~g} / \mathrm{dL}$. As she was steroid resistant, renal biopsy was done with biopty gun under USG guidance, which showed 15 glomeruli, all with mesangial sclerosis with proliferation. There was multifocal tubular atrophy. Blood vessels were mildly thickened. Immunofluorescence stains showed mesangial and peripheral granular deposits of $\operatorname{IgM}$ and C3c. [Figure 1] Serology for TORCH and HIV infection was negative and her karyotype was 46, XX.

Genetic mutation studies were not done as parents did not give consent for it. Electron microscopy, done with the paraffin block at a later date after getting light microscopy findings, showed four glomeruli, out of which one is completely sclerosed. One glomeruli showed mild wrinkling and irregularity of capillary loops but appears to be of usual thickness. Glomerular sections showed prominent paraffin artifact but wherever foot processes were visible appeared to be intact. There is mild mesangial expansion without mesangial deposits with mild microcystic tubular dilatation. This can represent an example of Finnish nephropathy. [Figure 2] She was started on enalapril at $0.2 \mathrm{mg} / \mathrm{kg} /$ day for antiproteinuric effects. She was maintained on diuretics as and when needed along with calcium supplements. After 4 weeks she had severe infection and died of florid sepsis.

\section{Discussion \& Conclusion}

Diffuse mesangial sclerosis, a rare manifestation of nephrotic syndrome in infancy, is either an isolated disease 


\section{Udani et al; Isalated Diffuse Mesangial Sclerasis}

with autosomal dominant or recessive inheritance due to mutation in WT1 or PLCE1 gene respectively. It can be part of a syndrome like Denys-Drash (DDS) or Pierson syndrome due to mutation in WT1 or LAMB2 gene respectively. ${ }^{[2,3]}$ DDS usually presents with SRNS, Wilms tumor with or without ambiguous genitalia. Pierson syndrome has ocular involvement affecting cornea, lens or retina. Our patient had onset of NS after 1 year with no hypertension or renal failure or microcoria, female phenotype and genotype and no evidence of Wilms tumor. DMS usually has poor prognosis with progression to end stage renal disease (ESRD) frequently in association with hypertension before the age of 3 years or within few months of diagnosis of renal disease. ${ }^{[4]}$ Treatment is supportive with adequate calories, prevention and treatment of infections and treatment of renal failure through dialysis. ${ }^{[5]}$ The antiproteinuric action of ACE inhibitors with or without NSAIDs may reduce proteinuria by decreasing GFR and can be used in infancy especially before nephrectomy is performed. ${ }^{[6-8]}$ The disease does not recur after transplantation. ${ }^{[4]}$

Table 1: Approach to gene mutation with renal biopsy and clinical findings.

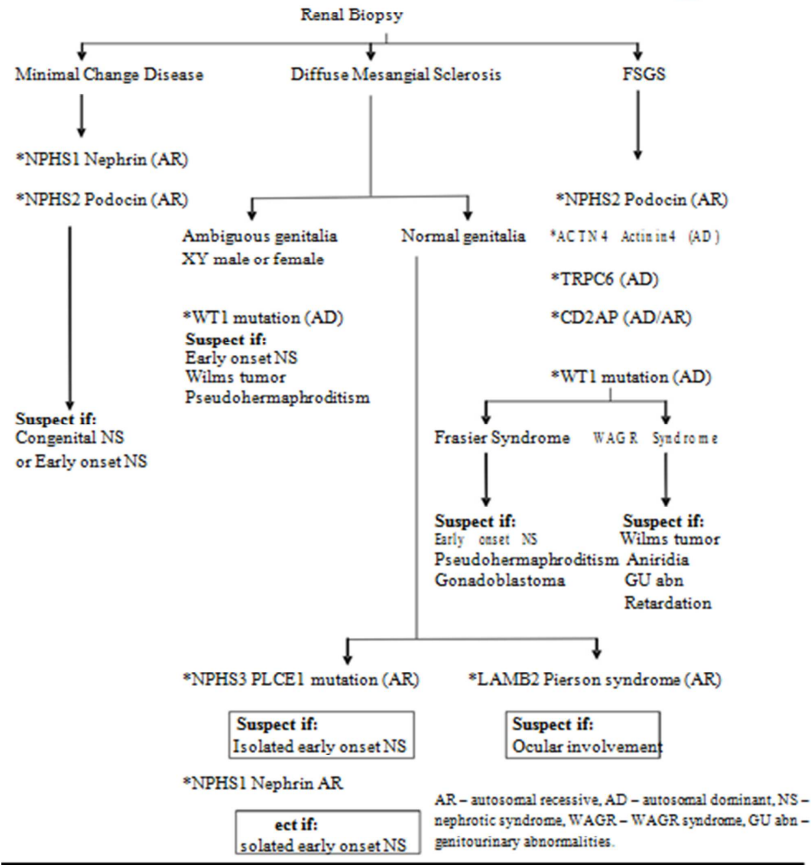

Mortality is often seen due to septicemia in these children to which our patient also succumbed. Genetic mutation studies should be done to find out the component of filtration barrier affected in these children for genetic counseling and prognosis. $^{[9]}$

Renal biopsy should be performed in all children presenting as SRNS to identify underlying pathology to narrow down the possibility of underlying gene mutation in these children especially when genetic studies are not widely available in countries with limited resources. [Table 1] DMS and NPHS1 mutation has been described but usually they present with congenital nephrotic syndrome with proximal tubular dilatations (microcysts) on biopsy.[10] Our child most possibly had minor NPHS1 mutation as she presented after infancy for the first time without any extra renal manifestations with DMS in light microscopy and microcystic tubular dilatation with intact foot process on electron microscopy. ${ }^{[11]}$

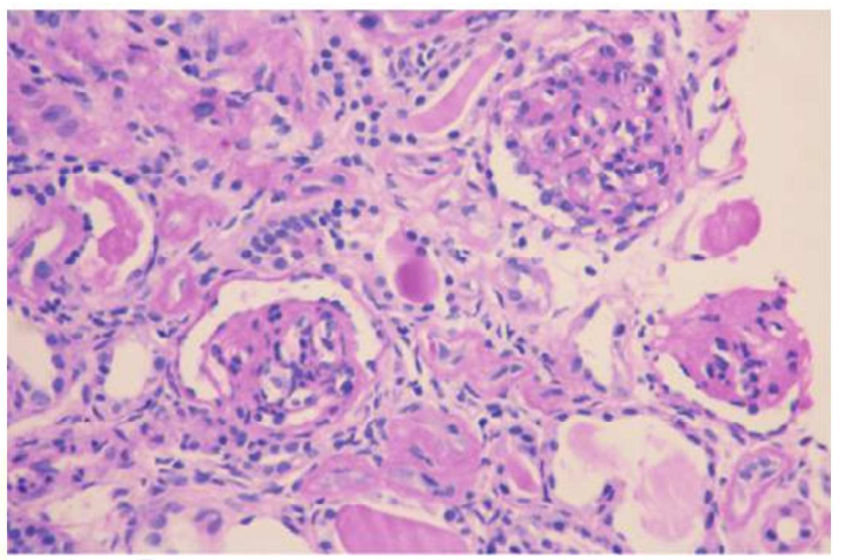

Figure 1: Light microscopy of kidney biopsy showing features of mesangial sclerosis.

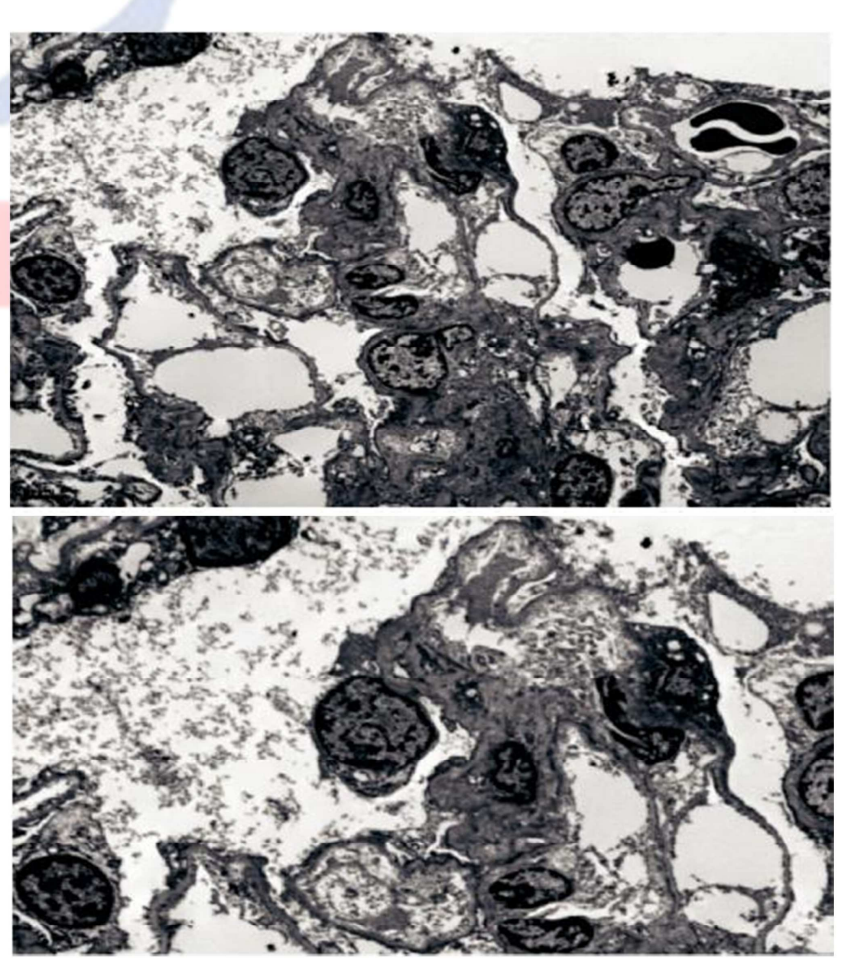

Figure 2a\&b: Electron microscopy showing mild mesangial matrix expansion and cystic tubular dilatation

\section{References}

1. Umesh L, Prashanth A, Benakappa DG, Govindaraj M, Benakappa N. Diffuse mesangial sclerosis presenting as infantile nephrotic 
syndrome. Indian Pediatr 2001;38:663-4.

2. Jalanko H. Congenital nephrotic syndricome. Pediatr Nephrol 2009;24:2121-38.

3. Gbadegesin R, Hinkes BG, Hoskins BE, Vlangos CN, Heeringa SF, Liu J, et al. Mutations in PLCE1 are a Major Cause of Isolated Diffuse Mesangial sclerosis (IDMS). Nephrol Dial Transplant 2008;23:1291-97.

4. Niaudet P. Diffuse mesangial sclerosis. Orphanet encyclopedia May 2004 www.orpha.net/data/patho/GB/uk-DMS.pdf. Accessed on 20th August 2012.

5. Jalanko H. Congenital nephrotic syndricome. Pediatr Nephrol 2009;24:2121-38.

6. Heaton PAJ, Smlaes O, Wong W. Congenital nephrotic syndrome responsive to captopril and indomethacin. Arch Dis Child 1999;81:174-5.
7. Pomeranz A, Wolach B, Benheim J, Korzets Z. Successful treatment of Finnish Congenital nephrotic syndrome with Captopril and Indomethacin. J Pediatr 1995;126:140-2.

8. Umesh L, Prashanth A, Benakappa DG, Govindaraj M, Benakappa N. Diffuse mesangial sclerosis presenting as infantile nephrotic syndrome. Indian Pediatr 2001;38:663-4.

9. Machuca E, Esquivel EL, Antignac C. Idiopathic nephrotic syndrome: Genetic aspects. In Avner ED, Harmon WE, Niaudet P, Yoshikawa N eds. Pediatric Nephrology 6 ed.

10. Caridi G, Trivelli A, Sanna-Cherchi S, Perfumo F, Ghiggeri GM. Familial forms of nephrotic syndrome. Pediatr Nephrol 2010;(25):241-52.

11. Benoit G, Machuca E, Antignac C. Hereditary nephrotic syndrome: a systematic approach for genetic testing and a review of associated podocyte gene mutations. Pediatr Nephrol 2010:(25):1621-32.

Copyright: (C) the author(s), publisher. Asian Journal of Clinical Pediatrics and Neonatology is an Official Publication of "Society for Health Care \& Research Development". It is an open-access article distributed under the terms of the Creative Commons Attribution NonCommercial License, which permits unrestricted non-commercial use, distribution, and reproduction in any medium, provided the original work is properly cited.

How to cite this article: Udani A, Vijayakumar M, Prahlad N, Sudha E. Isolated Diffuse Mesangial Sclerosis Presenting as Steroid Resistant Nephrotic Syndrome After Infancy. Asian J. Clin. Pediatr. Neonatol.2018;6(3):1-3.

DOI: dx.doi.org/10.21276/ajcpn.2018.6.3.1

Source of Support: Nil, Conflict of Interest: None declared. 